\title{
KEANEKARAGAMAN DAN KEGUNAAN TUMBUHAN BAWAH PADA BEBERAPA TEGAKAN DI ARBORETUM BALAI PENELITIAN DAN PENGEMBANGAN TEKNOLOGI SERAT TANAMAN HUTAN (BP2TSTH) KUOK
}

\author{
Diversity And Use Of Undergraduate Plants In Some Establishments In The Arboretum Of \\ The Kuok Forest Fiber Fiber (BP2TSTH) Arboretum \\ Arifin Budi Siswanto ${ }^{1}$ Hadinoto $^{2}$, Azwin ${ }^{2}$ \\ 1) Jurusan Kehutanan Fakultas Kehutanan Universitas Lancang Kuning \\ 2 ) Staff Pengajar Fakultas Kehutanan Universitas Lancang Kuning \\ Jalan Yos Sudarso Km.08 Rumbai, Pekanbaru \\ Email : arifin.bs31@gmail.com, hadinoto@unilak.ac.id,azwin@unilak.ac.id
}

Diterima: 12 Januari 2021, Direvisi: 21 Januari 2021, Disetujui: 21 Juli 2021

DOI: $10.31849 /$ forestra.v16i2.5883

\section{ABSTRACT}

Underground plants have an important role in soil and air conservation efforts, namely as a source of organic matter, preventing erosion, a source of germplasm and increasing air infiltration into the soil. This study aims to identify the types, diversity and use of understorey under stands of meranti, gaharu and mixed stands in the arboretum of the Kuok Forest Plant Fiber Technology Research and Development Institute (BP2TSTH). The data collection method used systematic sampling with a random start, with a sampling intensity of 5\%. The number of plots observed for meranti, gaharu and mixed stands were 50, 25 and 25, respectively, with a plot size of $2 \times 2(\mathrm{~m})$. In the stands were found 17 families of undergrowth consisting of 23 species and 10,338 individuals. In the agarwood stands there are 10 families of undergrowth consisting of 13 species and 9,696 individuals. In the agarwood stands there are 11 families with a diversity of 13 species and 10,328 individuals. Diversity Index and Evenness Index in meranti, gaharu and mixed stands respectively; 1.25 and 0.4; 0.72 and 0.28; 0.72 and 0.28. Paspalum conjugatum is a understorey species with the highest Importance Value Index (IVI) in the three stands.

Keywords: Diversity and Usefulness, Lower Plants, Stands

\begin{abstract}
ABSTRAK
Tumbuhan bawah memiliki peran penting dalam upaya konservasi tanah dan air yaitu sebagai sumber bahan organik, pencegah erosi, sumber plasma nutfah dan meningkatkan infiltrasi air ke dalam tanah. Penelitian ini bertujuan mengidentifikasi jenis, keanekaragaman dan kegunaan tumbuhan bawah di bawah
\end{abstract}


tegakan meranti, gaharu dan tegakan campuran di arboretum Balai Penelitian dan Pengembangan Teknologi Serat Tanaman Hutan (BP2TSTH) Kuok. Metode pengambilan data menggunakan systematic sampling with random start, dengan intensitas sampling sebesar 5\%. Jumlah plot yang diamati untuk tegakan meranti, gaharu dan campuran masing-masing sebanyak 50, 25 dan 25, dengan ukuran masingmasing plot $2 \times 2(\mathrm{~m})$. Pada tegakan meranti ditemukan 17 famili tumbuhan bawah yang terdiri dari 23 jenis dan 10.338 individu. Pada tegakan gaharu terdapat 10 famili tumbuhan bawah yang terdiri dari 13 jenis dan 9.696 individu. Pada tegakan gaharu terdapat 11 famili dengan keragaman jenis sebanyak 13 dan jumlah individu sebanyak 10.328. Indeks Keanekaragaman dan Indeks Kemerataan pada tegakan meranti, gaharu dan campuran secara berturut-turut; 1,25 dan 0,4;0,72 dan 0,28; 0,72 dan 0,28. Paspalum conjugatum merupakan spesies tumbuhan bawah dengan Indeks Nilai Penting (INP tertinggi pada ketiga tegakan.

Kata Kunci: Keanekaragaman dan Kegunaan, Tumbuhan Bawah, Tegakan

\section{PENDAHULUAN}

Indonesia merupakan negara tropis yang dilalui garis khatulistiwa, dan terletak di antara dua benua (Asia dan Australia) dan dua samudra, (Pasifik dan Hindia). Sebagai negara tropis, Indonesia memiliki keanekaragaman hayati yang sangat tinggi. Keanekaragaman hayati Indonesia dapat diterangkan dengan teori lempeng tektonik, yang terbagi menjadi beberapa sub region menggunakan Garis Wallace, Garis Weber dan Garis Lydekker (KLHK, 2018). Salah satu keanekaragaman hayati tersebut adalah tumbuhan bawah yang salah satunya berperan penting dalam upaya konservasi tanah dan air di Indonesia. Salah satu fungsi tumbuhan bawah adalah tambahan sumber bahan organik, mengurangi energi kinetik dari hujan dan kekuatan aliran permukaan di atas tanah, untuk mencegah erosi oleh air (Hanafiah, 2005). Abdiyani (2008), menyatakan bahwa tumbuhan bawah berperan penting dalam keberlangsungan ekosistem. Peran penting itu antara lain adalah penyediaan unsur hara, mengendalikan erosi, membantu meningkatkan proses masuknya air kedalam tanah (infiltrasi), sebagai sumber plasma nutfah, sumber obat-obatan, pakan ternak dan satwa hutan, serta manfaat lainnya yang belum diketahui. Hal ini menunjukkan bahwa keberadaan tumbuhan bawah di hutan tanaman menjadi sangat penting dan tidak bisa diabaikan.

Jenis meranti (Shorea spp.) dan gaharu (Aquilaria malaccensis) merupakan salah satu jenis tanaman kehutanan yang telah memiliki nilai ekonomi tinggi dan 
dibudidayakan oleh masyarakat Indonesia.

Menurut Kunarso dan Azwar (2013), meranti merupakan jenis pohon yang dikembangkan pada hutan tanaman yang termasuk dalam kelompok kayu pertukangan. Pohon gaharu merupakan jenis penghasil gaharu yang bisa memberikan keuntungan ekonomi bagi masyarakat.

Arboretum menurut Kamus Besar Bahasa Indonesia dapat diartikan sebagai tempat berbagai pohon ditanam dan dikembangbiakan untuk tujuan penelitan dan pendidikan. Dalam arti luas arboretum didefinisikan sebagai kebun koleksi pepohonan dengan luasan tertentu berisi berbagai jenis pohon yang ditanam sedapat mungkin mengikuti habitat aslinya dan dimaksudkan sebagai areal pelestarian keanekaragaman hayati dan sedikitnya dapat memperbaiki atau menjaga kondisi iklim di sekitarnya.

Tumbuhan bawah adalah suatu jenis vegetasi dasar yang terdapat di bawah tegakan selain permudaan pohon hutan, yang meliputi rerumputan dan vegetasi semak belukar. Jenis-jenis pohon kecil (perdu), semak-semak, dan tumbuhan bawah serta liana perlu dipelajari juga karena merupakan indikator tempat tumbuh, merupakan pengganggu bagi pertumbuhan permudaan pohon-pohon penting, penting sebagai penutup tanah dan penting dalam pencampuran serasah dan pembentukan bunga tanah (Soerianegara dan Indrawan 2008).

Sampai saat ini belum ada penelitian tentang tumbuhan bawah pada tegakan meranti dan gaharu di arboretum Balai Penelitian dan Pengembangan Teknologi Serat Tanaman Hutan (BP2TSTH) Kuok. Oleh karena itu, perlu dilakukan studi tentang analisa tumbuhan bawah pada tegakan meranti dan gaharu di arboretum Balai Penelitian dan Pengembangan Teknologi Serat Tanaman Hutan (BP2TSTH) Kuok sehingga dapat diketahui jenis, komposisi dan kegunaannya.

\section{METODE PENELITIAN}

\section{a. Waktu dan Tempat Penelitian}

Penelitian dilakukan selama 2 bulan dari bulan Maret-April 2020. Tempat penelitian dilaksanakan di arboretum Balai Penelitian dan Pengembangan Teknologi serat 
Tanaman Hutan (BP2TSTH) Kuok. Secara administrasi berada di Desa Kuok, Kecamatan Kuok, Kabupaten Kampar, Provinsi Riau.

\section{b. Pembuatan Plot}

Pembuatan plot dilakukan di bawah tegakan meranti, gaharu dan campuran. Pengambilan sampel petak ukur dilakukan dengan menggunakan metode systematic sampling with random start dengan intensitas sampling sebesar $5 \%$. Menurut Soerianegara dan Indrawan (2008) untuk kelompok hutan yang luasnya kurang dari 1.000 ha dapat menggunakan intensitas sampling antara 5-10\%, sedangkan ukuran petak ukur untuk tumbuhan bawah adalah 2 x 2 (m) (Indriyanto, 2006). Tegakan meranti memiliki luas $4.000 \mathrm{~m}^{2}$ dengan ukuran $50 \mathrm{x}$ 80 (m), sehingga petak ukur yang dibuat adalah 50 petak ukur, tegakan gaharu dan tegakan campuran masing-masing memiliki luas $2.000 \mathrm{~m}^{2}$ dengan ukuran 40 x 50 (m) sehingga petak ukur yang dibuat pada masing-masing tegakan adalah 25 petak ukur. Bentuk petak ukur yang diamati dengan ukuran 40 x 50 (m) disajikan pada Gambar 1.

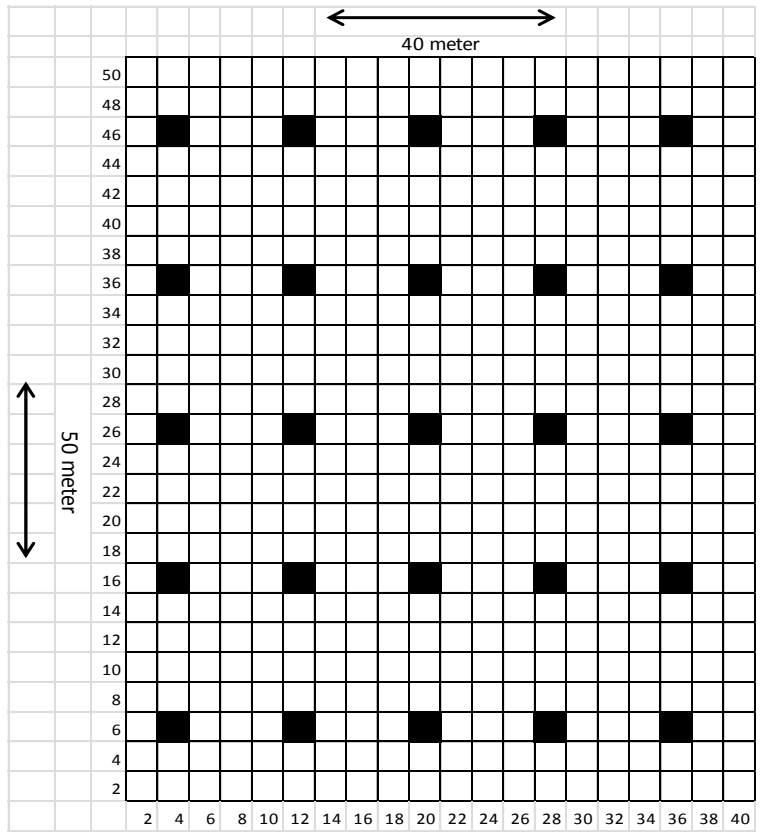

Gambar 1. Bentuk Petak Ukur dan Susunan Petak Ukur

\section{c. Identifikasi Jenis dan Identifikasi Kegunaan}

Identifikasi jenis-jenis tumbuhan bawah dibantu oleh pengenal vegetasi dari masyarakat setempat dan menggunakan buku identifikasi tumbuhan bawah. Buku identifikasi spesies tumbuhan bawah yang digunakan yaitu Karyati dan Adhi (2018) dan Yassir dan Sitepu (2015) serta Ngatiman dan Budiono (2010). Identifikasi kegunaan 
tumbuhan bawah dilakukan dengan mencari

studi pustaka, wawancara dengan narasumber pembuat obat herbal dan peternak hewan ternak.

\section{Analisis Data}

Indeks Nilai Penting (INP) (importance value index) adalah parameter kuantitatif yang dapat dipakai untuk menyatakan tingkat dominasi (tingkat penguasaan) spesiesspesies dalam suatu komunitas tumbuhan bawah. Pada tumbuhan bawah, suatu jenis dikatakan dominan apabila jenis yang bersangkutan ditemukan dalam jumlah yang banyak dan tersebar merata di seluruh areal, sehingga penetapan suatu jenis dominan berdasarkan indeks nilai penting. Indeks Nilai Penting dari tumbuhan bawah didapat dari perhitungan sebagai berikut :

Rumus yang digunakan untuk menghitung Indeks Nilai Penting (INP) (Soerianegara dan Indrawan 2008) :

a. Kerapatan suatu jenis $(\mathrm{K})$, dihitung rumus

$$
\text { : } \quad K=\frac{\text { Jumlah individu suatu jenis }}{\text { Luas Petak Contoh }}
$$

b. Kerapatan Relatif (KR) suatu jenis, dihitung dengan rumus :

$$
K R=\frac{\text { Kerapatan Suatu Jenis }}{\text { Kerapatan Semua Jenis }} \times 100 \%
$$

c. Frekuensi (F) suatu jenis, dihitung dengan rumus :

$$
F=\frac{\text { Jumlah Petak ditemukan suatu jenis }}{\text { Jumlah Seluruh petak contoh }}
$$

d. Frekuensi Relatif (FR) suatu jenis, dihitung dengan rumus :

$$
\mathrm{FR}=\frac{\text { Frekuensi suatu jenis }}{\text { Frekuensi Seluruh Jenis }} \times 100 \%
$$

e. INP (untuk tingkat semai) $=\mathrm{KR}+\mathrm{FR}$

Keanekaragaman tumbuhan dalam penelitian ini dianalisis dengan menggunakan indeks keanekaragaman Shannon Wiener yang diperoleh dengan parameter kekayaan jenis dan proporsi kelimpahan masingmasing jenis di suatu habitat. Kelimpahan dinyatakan dalam jumlah individu dari masing-masing jenis dan kekayaan jenis dinyatakan dalam jumlah jenis di setiap petak penelitian. Nilai indeks keanekaragaman menurut Odum (1971) dalam Fachrul (2012) rumusnya untuk indeks keanekaragaman jenis dari Shannon-Winer adalah :

$$
\mathrm{H}^{\prime}=\sum_{i=1}^{s}(\rho i)(\ln \rho i)
$$

Dimana :

$$
\begin{aligned}
\mathrm{H}^{\prime}= & \text { Indeks keanekaragaman } \\
& \text { Shannon-Wiener } \\
\mathrm{S}= & \text { Jumlah Jenis }
\end{aligned}
$$




$$
\begin{array}{ll}
\mathrm{ni} & =\text { Jumlah individu jenis } \mathrm{ke}-\mathrm{i} \\
\mathrm{N} & =\text { Total seluruh individu }
\end{array}
$$

Kerapatan suatu spesies menunjukkan jumlah individu spesies dengan satuan luas tertentu, maka nilai kerapatan merupakan gambaran mengenai jumlah spesies tersebut pada lokasi pengamatan. Untuk mengetahui keberadaan nilai keanekaragaman, maka indeks Shannon Wiener dikategorikan kedalam tiga kriteria :

Tabel 1. Kriteria Indeks Keanekaragaman Shannon-Wiener

\begin{tabular}{cc}
\hline $\begin{array}{c}\text { Nilai Indeks } \\
\text { Shannon-Winner }\end{array}$ & Kategori \\
\hline $\mathrm{H}^{\prime}<1$ & Keanekaragaman rendah \\
$1 \leq \mathrm{H}^{\prime} \leq 3$ & Keanekaragaman sedang \\
$\mathrm{H}^{\prime} \geq 3$ & Keanekaragaman tinggi \\
\hline
\end{tabular}

Untuk mengetahui struktur komunitas pohon dalam plot penelitian maka dihitung nilai indeks kemerataan antar jenis yang umum dipergunakan yakni ((Ludwig dan Reynold 1988 dalam Silmi 2017), dengan rumus sebagai berikut :

$$
E=\frac{H^{\prime}}{\ln (s)}
$$

Dimana :

$$
\mathrm{E}=\text { Indeks kemerataan }
$$

$$
\begin{aligned}
\mathrm{H}^{\prime}= & \text { Indeks keanekaragaman } \\
& \text { Shannon-Wiener } \\
\mathrm{S}= & \text { Jumlah jenis }
\end{aligned}
$$

Menurut Magurran (1988) dalam Destaranti et al. (2017) untuk indeks kemerataan (E) dengan nilai $\mathrm{E}<0,3$ termasuk dalam kemerataan jenis yang rendah, nilai E 0,3-0,6 termasuk dalam kemerataan jenis yang sedang dan jika nilai $\mathrm{E}>0,6$ termasuk dalam kemerataan jenis yang tinggi. Indeks kemerataan dikategorikan kedalam tiga kriteria.

Tabel 2. Kriteria Indeks Kemerataan

\begin{tabular}{cc}
\hline $\begin{array}{c}\text { Indeks } \\
\text { kemerataan }\end{array}$ & Kategori \\
\hline$<0,3$ & Indeks kemerataan jenis rendah \\
$0,3-0,6$ & Indeks kemerataan jenis sedang \\
$>0,6$ & Indeks kemerataan jenis tinggi \\
\hline
\end{tabular}

Data jenis tumbuhan bawah yang telah diperoleh dianalisis secara dekriptif, yaitu mengelompokkan jenis-jenis tumbuhan bawah berdasarkan lokasi penelitian, famili dan kegunaannya. Untuk kegunaannya diperoleh dari berbagai studi pustaka, wawancara dengan narasumber pembuat obat herbal dan narasumber peternak hewan ternak. 


\section{HASIL DAN PEMBAHASAN}

\section{a. Kondisi Tegakan dan Lingkungan}

Tegakan meranti dan gaharu yang diamati dalam penelitian ini berumur 14 tahun, dengan masing-masing jarak tanam $4 \mathrm{x}$ 4 (m). Pada tegakan campuran umurnya bervariasi antara 5-25 tahun, dengan jarak tanam yang tidak teratur. Hasil rata-rata pengukuran dimensi pohon pada tegakan meranti, gaharu dan campuran yang meliputi pengukuran tinggi, diameter dan diameter tajuk disajikan pada Tabel 3.

Tabel 3. Ukuran Rata-rata Dimensi Pohon di Tiga Lokasi Tegakan

\begin{tabular}{|c|c|c|c|c|}
\hline \multirow[b]{2}{*}{ No. } & \multirow[b]{2}{*}{ Lokasi } & \multicolumn{3}{|c|}{$\begin{array}{c}\text { Rata-rata ukuran dimensi } \\
\text { pohon }\end{array}$} \\
\hline & & $\begin{array}{l}\text { Tinggi } \\
\text { (m) }\end{array}$ & $\begin{array}{l}\text { Diameter } \\
\text { (cm) }\end{array}$ & $\begin{array}{c}\text { Diameter } \\
\text { tajuk } \\
(\mathrm{cm})\end{array}$ \\
\hline 1 & $\begin{array}{l}\text { Tegakan } \\
\text { Meranti }\end{array}$ & 14,7 & 20,2 & 650 \\
\hline 2 & $\begin{array}{l}\text { Tegakan } \\
\text { Gaharu }\end{array}$ & 9,2 & 19,0 & 480 \\
\hline 3 & $\begin{array}{l}\text { Tegakan } \\
\text { Campuran }\end{array}$ & 10,2 & 16,9 & 610 \\
\hline
\end{tabular}

Tabel 3 menunjukkan tegakan meranti memiliki rata-rata tinggi dan diameter pohon yang lebih besar dibanding tegakan gaharu dan campuran. Rata-rata tinggi pohon dan diameter di tegakan meranti yaitu 14,7 m dan 20,2 cm. Sementara itu, di tegakan campuran, rerata tinggi dan diameter pohon lebih rendah daripada di tegakan meranti, yaitu 10,2 m dan $16,9 \mathrm{~cm}$. Pada tegakan gaharu, rerata tinggi dan diameter pohon lebih kecil dibanding di tegakan meranti dan campuran. Rerata tinggi dan diameter pohon adalah 9,2 $\mathrm{m}$ dan 19,0 cm. Pada pengamatan parameter diameter tajuk, ukuran terlebar terdapat pada tegakan meranti yang memiliki diameter tajuk 650 (cm). Ukuran diameter tajuk pada tegakan campuran dan gaharu lebih kecil daripada di tegakan meranti, yaitu secara berturut-turut $610 \mathrm{~cm}$ dan $480 \mathrm{~cm}$.

Data hasil pengukuran kondisi lingkungan berupa suhu udara, kelembaban udara dan intensitas cahaya pada tegakan meranti, gaharu dan campuran disajikan pada Tabel 4.

Tabel 4. Suhu Udara, Kelembaban Udara dan Intensitas Cahaya di 3 Lokasi Tegakan

\begin{tabular}{ccc}
\hline Tegakan & Suhu Udara & Kelembaban \\
& $\left({ }^{\circ} \mathrm{c}\right)$ & Udara $(\%)$
\end{tabular}




\begin{tabular}{|c|c|c|c|c|c|c|}
\hline & $\begin{array}{c}\text { Pag } \\
\text { i }\end{array}$ & $\begin{array}{c}\text { Sian } \\
\mathrm{g}\end{array}$ & Sor & $\begin{array}{c}\mathrm{Pag} \\
\mathrm{i}\end{array}$ & $\underset{\mathbf{g}}{\operatorname{Sian}}$ & Sor \\
\hline Meranti & $\begin{array}{c}25 \\
2\end{array}$ & 31,6 & $\begin{array}{c}31, \\
5\end{array}$ & 94 & 63 & 64 \\
\hline Gaharu & $\begin{array}{c}25 \\
3\end{array}$ & 31,9 & $\begin{array}{c}31 \\
4\end{array}$ & 92 & 65 & 66 \\
\hline $\begin{array}{l}\text { Campura } \\
\mathrm{n}\end{array}$ & $\begin{array}{c}25 \\
4\end{array}$ & 32,5 & $\begin{array}{c}31, \\
6\end{array}$ & 95 & 59 & 67 \\
\hline
\end{tabular}

\begin{tabular}{lccc}
\hline \multirow{2}{*}{ Tegakan } & \multicolumn{3}{c}{ Intensitas Cahaya } \\
& \multicolumn{3}{c}{ (lux meter) } \\
\cline { 2 - 4 } & Pagi & Siang & Sore \\
\hline Meranti & 730 & 7.715 & 1.541 \\
Gaharu & 2.092 & 16.281 & 5.337 \\
Campuran & 1.858 & 21.135 & 6.081 \\
\hline
\end{tabular}

Secara umum hasil menunjukkan suhu udara pada pagi dan sore hari di ketiga lokasi tegakan adalah sama, akan tetapi pada siang hari terdapat perbedaan suhu di ketiga lokasi tersebut (Tabel 4). Pada siang hari, suhu udara di tegakan campuran adalah $32,5^{\circ} \mathrm{C}$, sedangkan suhu udara siang hari di tegakan meranti dan gaharu, secara berturut-turut adalah $31,6^{\circ} \mathrm{C}$ dan $31,9^{\circ} \mathrm{C}$. Pada parameter kelembaban udara, ketiga lokasi memiliki kelembaban udara yang sama pada pagi dan sore hari, namun pada siang hari memiliki perbedaan yang mencolok. Pada siang hari, kelembaban udara di tegakan gaharu lebih tinggi daripada di tegakan campuran maupun meranti. Secara berturut-turut, kelembaban udara di tegakan gaharu, meranti dan campuran pada siang hari yaitu $65 \%, 63 \%$ dan $59 \%$.

Intensitas cahaya di ketiga lokasi penelitian terlihat berbeda pada pagi, siang dan sore hari. Di lokasi tegakan meranti, intensitas cahaya pada pagi, siang dan sore hari lebih rendah daripada di lokasi tegakan campuran dan gaharu. Di lokasi tegakan campuran, intensitas cahaya pada siang hari lebih tinggi daripada intensitas cahaya pada pagi dan sore hari. Suhu udara dan intensitas cahaya di tegakan meranti lebih rendah dibandingkan dengan di tegakan gaharu dan campuran disebabkan oleh faktor diameter tajuk. Di tegakan meranti, yang memiliki lebar tajuk $650(\mathrm{~cm})$, mengakibatkan sebagian cahaya matahari tidak bisa menembus permukaan tanah sehingga diduga dengan kondisi seperti ini, maka intensitas cahaya dan suhu udara di tegakan meranti lebih rendah dibandingkan dengan di tegakan gaharu maupun campuran. Hal sebaliknya terjadi di tegakan gaharu, dengan diameter 
tajuk yang lebih rendah daripada di tegakan meranti dan tegakan campuran, yaitu (480 $\mathrm{cm})$, mengakibatkan cahaya matahari banyak yang menembus permukaan tanah sehingga suhu udara dan intensitas cahayanya lebih tinggi.

\section{b. Tegakan Meranti}

Pada pengamatan tumbuhan bawah di tegakan meranti ditemukan 17 famili tumbuhan bawah yang terdiri dari 23 jenis, dengan jumlah individu sebanyak 10.154 (Tabel 5).

Tabel 5. Jenis, Famili dan Jumlah Individu Tumbuhan Bawah di Tegakan Meranti

\begin{tabular}{|c|c|c|c|c|}
\hline No. & Nama Ilmiah & $\begin{array}{l}\text { Nama } \\
\text { daerah }\end{array}$ & Famili & $\begin{array}{l}\text { Jumlah } \\
\text { Individu }\end{array}$ \\
\hline 1 & $\begin{array}{l}\text { Asystasia } \\
\text { gangetica }\end{array}$ & $\begin{array}{l}\text { Rumput } \\
\text { israel }\end{array}$ & Acathaceae & 842 \\
\hline 2 & $\begin{array}{l}\text { Aristolochia } \\
\text { tagala }\end{array}$ & Kelayar & Aristolochiaceae & 2 \\
\hline 3 & $\begin{array}{l}\text { Blechnum } \\
\text { orientale }\end{array}$ & Paku lencir & Blechnaceae & 15 \\
\hline 4 & $\begin{array}{l}\text { Stenochlaena } \\
\text { palutris }\end{array}$ & Kelakai & Blechnaceae & 1 \\
\hline 5 & $\begin{array}{l}\text { Cyperus } \\
\text { rotundus L. }\end{array}$ & $\begin{array}{l}\text { Rumput } \\
\text { teki }\end{array}$ & Cyperaceae & 180 \\
\hline 6 & $\begin{array}{l}\text { Microlepia } \\
\text { speluncae }\end{array}$ & $\begin{array}{l}\text { Paku- } \\
\text { pakuan }\end{array}$ & Dennstaedtiaeae & 16 \\
\hline 7 & $\begin{array}{l}\text { Euphorbia } \\
\text { hirta }\end{array}$ & $\begin{array}{l}\text { Patikan } \\
\text { kebo }\end{array}$ & Euphorbiaceae & 6 \\
\hline 8 & Calopogonium & Kacang asu & Fabaceae & 81 \\
\hline
\end{tabular}

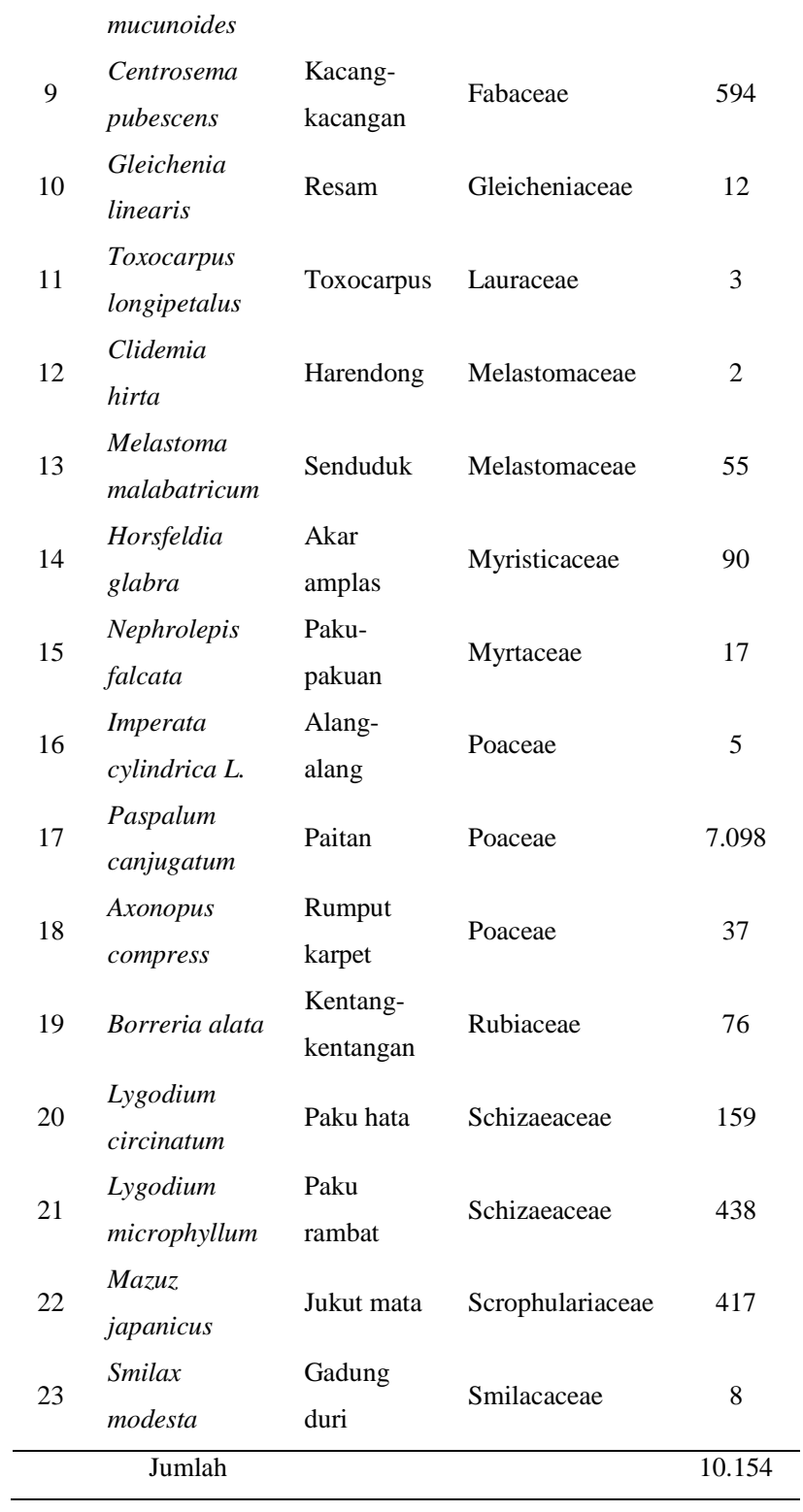

Pada Tabel 5 terlihat bahwa tumbuhan bawah dengan jumlah individu terbanyak adalah Paspalum conjugatum, yaitu sejumlah 7.098. P. conjugatum (famili Poaceae) yang memiliki nama daerah paitan, sedangkan, 
Stenochlaena palutris, (famili Blechnaceae) dengan nama daerah kelakai hanya ditemukan sebanyak satu individu. Lebih lanjut pada pengamatan keragaman jenis, nilai tertinggi terdapat pada pada famili Poaceae, yang terdiri dari Imperata cylindrica, P. conjugatum dan Axonopus compress.

Indeks Nilai Penting (INP) tumbuhan bawah yang berada pada tegakan meranti, ditampilkan pada Tabel 6 .

Tabel 6. Indeks Nilai Penting (INP) Tumbuhan Bawah di Tegakan Meranti

\begin{tabular}{llccccc}
\hline No. & Nama ilmiah & $\mathrm{K}$ & $\begin{array}{l}\text { KR } \\
(\%)\end{array}$ & F & $\begin{array}{l}\text { FR } \\
(\%)\end{array}$ & INP \\
\hline 1 & $\begin{array}{l}\text { Horsfeldia } \\
\text { glabra } \\
2\end{array}$ & 4.500 & 0,9 & 0,48 & 8,30 & 9,19 \\
& $\begin{array}{l}\text { Imperata } \\
\text { cylindrica L. }\end{array}$ & 250 & 0,0 & 0,02 & 0,35 & 0,40 \\
3 & $\begin{array}{l}\text { Aristolochia } \\
\text { tagala }\end{array}$ & 100 & 0,0 & 0,02 & 0,35 & 0,37 \\
4 & $\begin{array}{l}\text { Blechnum } \\
\text { orientale }\end{array}$ & 750 & 0,1 & 0,02 & 0,35 & 0,49 \\
5 & $\begin{array}{l}\text { Gleichenia } \\
\text { linearis }\end{array}$ & 600 & 0,1 & 0,06 & 1,04 & 1,16 \\
6 & $\begin{array}{l}\text { Clidemia } \\
\text { hirta }\end{array}$ & 100 & 0,0 & 0,04 & 0,69 & 0,71 \\
7 & $\begin{array}{l}\text { Calopogonium } \\
\text { mucunoides }\end{array}$ & 4.050 & 0,8 & 0,14 & 2,42 & 3,22 \\
8 & $\begin{array}{l}\text { Centrosema } \\
\text { pubescens } \\
9\end{array}$ & 29.700 & 5,8 & 0,84 & 14,53 & 20,38 \\
Borreria alata & 3.800 & 0,7 & 0,24 & 4,15 & 4,90
\end{tabular}

\begin{tabular}{|c|c|c|c|c|c|c|}
\hline 10 & $\begin{array}{l}\text { Lygodium } \\
\text { circinatum }\end{array}$ & 7.950 & 1,6 & 0,30 & 5,19 & 6,76 \\
\hline 11 & $\begin{array}{l}\text { Lygodium } \\
\text { microphyllum }\end{array}$ & 21.900 & 4,3 & 0,62 & 10,73 & 15,04 \\
\hline 12 & $\begin{array}{l}\text { Mazuz } \\
\text { japanicus }\end{array}$ & 20.850 & 4,1 & 0,28 & 4,84 & 8,95 \\
\hline 13 & $\begin{array}{l}\text { Microlepia } \\
\text { speluncae }\end{array}$ & 800 & 0,2 & 0,08 & 1,38 & 1,54 \\
\hline 14 & $\begin{array}{l}\text { Nephrolepis } \\
\text { falcata }\end{array}$ & 850 & 0,2 & 0,02 & 0,35 & 0,51 \\
\hline 15 & $\begin{array}{l}\text { Paspalum } \\
\text { canjugatum }\end{array}$ & 354.900 & 69,9 & 0,96 & 16,61 & 86,51 \\
\hline 16 & $\begin{array}{l}\text { Euphorbia } \\
\text { hirta }\end{array}$ & 300 & 0,1 & 0,04 & 0,69 & 0,75 \\
\hline, 17 & $\begin{array}{l}\text { Asystasia } \\
\text { gangetica }\end{array}$ & 42.100 & 8,3 & 0,76 & 13,15 & 21,44 \\
\hline 18 & $\begin{array}{l}\text { Axonopus } \\
\text { compress }\end{array}$ & 1.850 & 0,4 & 0,20 & 3,46 & 3,82 \\
\hline 19 & $\begin{array}{l}\text { Cyperus } \\
\text { rotundus L. }\end{array}$ & 9.000 & 1,8 & 0,32 & 5,54 & 7,31 \\
\hline 20 & $\begin{array}{l}\text { Melastoma } \\
\text { malabatricum }\end{array}$ & 2.750 & 0,5 & 0,22 & 3,81 & 4,35 \\
\hline 21 & $\begin{array}{l}\text { Smilax } \\
\text { modesta }\end{array}$ & 400 & 0,1 & 0,08 & 1,38 & 1,46 \\
\hline 22 & $\begin{array}{l}\text { Stenochlaena } \\
\text { palutris }\end{array}$ & 50 & 0,0 & 0,02 & 0,35 & 0,36 \\
\hline 23 & $\begin{array}{l}\text { Toxocarpus } \\
\text { longipetalus }\end{array}$ & 150 & 0,0 & 0,02 & 0,35 & 0,38 \\
\hline & Jumlah & 507.700 & 100,0 & 5,78 & 100,00 & 200,00 \\
\hline
\end{tabular}

Dari Tabel 6 diketahui bahwa lima jenis tumbuhan bawah yang memiliki nilai INP tertinggi adalah adalah $P$. conjugatum (86,51), Asystasia gangetica (21,44), Cenrosema pubescens (20,38), Lygodium microphyllum $(15,04)$ dan Horsfeldia glabra $(9,19)$. $P$. conjugatum memiliki nilai INP 
tertinggi dan jumlah individu lebih banyak dibanding jenis tumbuhan bawah lainnya. $P$. conjugatum selalu mendominasi di setiap plot yang diamati. Faktor yang diduga menyebabkan jenis $P$. conjugatum dominan di setiap plot adalah kemudahan untuk tumbuh pada berbagai kondisi, pertumbuhan relatif cepat dan pertambahan jumlah individu lebih cepat dibandingkan jenis tumbuhan bawah lainnya. Hal ini sejalan dengan pendapat Jusfah (1984) yang menyatakan bahwa $P$. conjugatum adalah tumbuhan bawah yang berkembang biak dengan biji dan stolon, sehingga peluang untuk menyebar semakin besar, yang mengakibatkan tumbuhan ini bisa tumbuh dimana-mana, baik di tempat terbuka ataupun agak terlindungi. Lebih lanjut menurut Holm (1977) dalam Adriadi et al. (2012) menyatakan bahwa satu individu $P$. conjugatum dapat menghasilkan 1.500 biji serta bijinya mudah menyebar sehingga peluang untuk tumbuh dan berkembang biak juga semakin besar. Penelitian yang dilakukan oleh oleh Ngatiman dan Nurcahyono (2016) juga menemukan bahwa $P$. conjugatum juga memiliki INP tinggi di areal penanaman Shorea leprosula sistim TPTJ-SILIN PT. Balikpapan Forest Industries (PT.BFI). Pada penelitian tersebut, empat jenis tumbuhan bawah dengan dominasi tertinggi adalah Clidemia hirta, Mikania michranta, Echinocloa Colonum dan $P$. conjugatum.

Salah satu faktor yang mempengaruhi jumlah populasi tumbuhan bawah adalah intensitas cahaya. Hasil pengamatan menunjukkan bahwa intensitas cahaya yang rendah di tegakan meranti adalah diameter tajuk yang lebar. Tutupan tajuk atas tersebut juga menyebabkan kelembaban dan suhu yang relatif lebih rendah di tegakan meranti dibanding di tegakan gaharu dan campuran. Oleh karenanya, iklim mikro di bawah tegakan meranti terasa lebih teduh atau sejuk sehingga menjadi tempat tumbuh jenis pakupakuan. Hal ini sesuai dengan pendapat Kinho (2008) menyatakan bahwa tumbuhan paku cenderung menyukai tempat-tempat teduh dengan derajat kelembaban tinggi. Pengamatan menunjukkan terdapat enam jenis tumbuhan bawah berupa paku-pakuan pada tegakan di bawah meranti yaitu Blechnum orientale, Stenochlaena palutris, 
Microlepia spulancae, Gleichenia linearis, Nephrolepis falcate dan Lygodium microphyllum. Hal ini menyebabkan jenis tumbuhan bawah di tegakan meranti lebih bervariasi.

Hasil penghitungan nilai indeks keanekaragaman dan kemerataan jenis pada tegakan meranti ditampilkan pada Tabel 7.

Tabel 7. Indeks Keanekaragaman dan Indeks Kemerataan di Tegakan Meranti

\begin{tabular}{ccc}
\hline No. & Jenis Indeks & Nilai \\
\hline 1 & Indeks Keanekaragaman & 1,25 \\
2 & Indeks Kemerataan & 0,40 \\
\hline
\end{tabular}

Menurut Magurran (1988) dalam Pananjung (2013) jika nilai indeks keanekaragaman $\left(\mathrm{H}^{\prime}\right)<1$ maka tergolong rendah, (H'): 1-3 tergolong sedang dan (H') $>3$ tergolong tinggi. Dengan nilai indeks keanekaragaman (H') sebesar 1,25 seperti tampak pada Tabel 7, menunjukkan bahwa keanekaragaman tumbuhan bawah di tegakan meranti termasuk dalam kategori sedang. Sementara untuk indeks kemerataan (E) menurut Magurran (1988) dalam Destaranti et al. (2017), untuk nilai $\mathrm{E}<0,3$ termasuk dalam kemerataan jenis yang rendah, nilai $E$ :
0,3-0,6 termasuk dalam kemerataan jenis yang sedang dan jika nilai $\mathrm{E}>0,6$ termasuk dalam kemerataan jenis yang tinggi. Dengan nilai indeks kemerataan (E) sebesar 0,40 maka, indeks kemerataan tumbuhan bawah dibawah tegakan meranti termasuk dalam kategori sedang.

\section{c. Tegakan Gaharu}

Hasil pengamatan menunjukkan bahwa di bawah tegakan gaharu ditemukan 10 famili tumbuhan bawah dengan keragaman jenis sebanyak 13, dan jumlah individu sebanyak 9.696 individu (Tabel 8).

Tabel 8. Jenis, Famili dan Jumlah Individu Tumbuhan Bawah di Tegakan Gaharu

\begin{tabular}{clllr}
\hline No & $\begin{array}{l}\text { Nama } \\
\text { ilmiah }\end{array}$ & $\begin{array}{l}\text { Nama } \\
\text { daerah }\end{array}$ & Famili & $\begin{array}{c}\text { Jumla } \\
\mathrm{h}\end{array}$ \\
\hline 1 & $\begin{array}{l}\text { Asystasia } \\
\text { gangetica }\end{array}$ & $\begin{array}{l}\text { Rumput } \\
\text { israel }\end{array}$ & Acathaceae & 1.164 \\
& $\begin{array}{l}\text { Mikania } \\
2\end{array}$ & Mikania & Asteraceae & 228 \\
& micrantha & & & \\
3 & Microlepia & Paku- & Dennstaedtiae & 5 \\
& speluncae & pakuan & ae & \\
& Centrosem & Kacang- & & \\
4 & a & kacanga & Fabaceae & 233 \\
& pubescens & $\mathrm{n}$ & & \\
5 & Melastoma & Sendud & Melastomacea & 25
\end{tabular}

Arifin Budi Siswanto, Hadinoto, Azwin / Wahana Forestra: Jurnal Kehutanan Vol. 16 No. 02/2021 


\begin{tabular}{|c|c|c|c|c|}
\hline \multicolumn{5}{|c|}{$u m$} \\
\hline 6 & $\begin{array}{l}\text { Horsfeldia } \\
\text { glabra }\end{array}$ & $\begin{array}{l}\text { Akar } \\
\text { amplas }\end{array}$ & Myristicaceae & 6 \\
\hline 7 & $\begin{array}{l}\text { Imperata } \\
\text { cylindrica } \\
\text { L. }\end{array}$ & $\begin{array}{l}\text { Alang- } \\
\text { alang }\end{array}$ & Poaceae & 37 \\
\hline 8 & $\begin{array}{l}\text { Paspalum } \\
\text { canjugatum }\end{array}$ & Paitan & Poaceae & 7.861 \\
\hline 9 & $\begin{array}{l}\text { Axonopus } \\
\text { compress }\end{array}$ & $\begin{array}{l}\text { Rumput } \\
\text { karpet }\end{array}$ & Poaceae & 44 \\
\hline 10 & $\begin{array}{l}\text { Borreria } \\
\text { latifolia }\end{array}$ & $\begin{array}{l}\text { Kawat- } \\
\text { kawatan }\end{array}$ & Rubiaceae & 10 \\
\hline & & Kentang & & \\
\hline 11 & $\begin{array}{l}\text { Borreria } \\
\text { alata }\end{array}$ & $\begin{array}{l}- \\
\text { kentang } \\
\text { an }\end{array}$ & Rubiaceae & 1 \\
\hline 12 & $\begin{array}{l}\text { Lygodium } \\
\text { circinatum }\end{array}$ & $\begin{array}{l}\text { Paku } \\
\text { hata }\end{array}$ & Schizaeaceae & 14 \\
\hline 13 & $\begin{array}{l}\text { Mazuz } \\
\text { japanicus }\end{array}$ & $\begin{array}{l}\text { Jukut } \\
\text { mata }\end{array}$ & $\begin{array}{l}\text { Scrophulariac } \\
\text { eae }\end{array}$ & 68 \\
\hline & Jumlah & & & 9.696 \\
\hline
\end{tabular}

Pada Tabel 8 terlihat bahwa jenis tumbuhan bawah dengan jumlah individu dominan adalah $P$. conjugatum yang termasuk dalam famili Poaceae dengan jumlah individu sebanyak 7.861. Sementara itu, jenis tumbuhan bawah dengan jumlah individu paling sedikit adalah Borreria alata yang termasuk dalam famili Rubiaceae yakni sebanyak 1. Pada tingkat famili, keragaman jenis tumbuhan bawah tertinggi ditemukan pada Poaceae yang terdiri dari I. cylindrica, P. conjugatum dan A. compress.

Tabel 9. Indeks Nilai Penting (INP) Tumbuhan Bawah di Tegakan Gaharu

\begin{tabular}{clccccc}
\hline No. & Nama Ilmiah & K & $\begin{array}{c}\text { KR } \\
(\%)\end{array}$ & F & $\begin{array}{l}\text { FR } \\
(\%)\end{array}$ & INP \\
\hline 1 & $\begin{array}{l}\text { Paspalum } \\
\text { canjugatum }\end{array}$ & 786.100 & 81,1 & 1,00 & 22,73 & 103,80
\end{tabular}

$\begin{array}{lllllll}2 & \begin{array}{l}\text { Asystasia } \\ \text { gangetica }\end{array} & 116.400 & 12,0 & 0,92 & 20,91 & 32,91 \\ & \begin{array}{l}\text { Centrosema } \\ \text { pubescens }\end{array} & 23.300 & 2,4 & 0,80 & 18,18 & 20,58\end{array}$

\begin{tabular}{|c|c|c|c|c|c|c|}
\hline 4 & $\begin{array}{l}\text { Mikania } \\
\text { micrantha }\end{array}$ & 22.800 & 2,4 & 0,52 & 11,82 & 14,17 \\
\hline 5 & $\begin{array}{l}\text { Imperata } \\
\text { cylindrica } L \text {. }\end{array}$ & 3.700 & 0,4 & 0,28 & 6,36 & 6,75 \\
\hline 6 & $\begin{array}{l}\text { Melastoma } \\
\text { malabatricum }\end{array}$ & 2.500 & 0,3 & 0,20 & 4,55 & 4,80 \\
\hline 7 & $\begin{array}{l}\text { Axonopus } \\
\text { compress }\end{array}$ & 4.400 & 0,5 & 0.16 & 3,64 & 4,09 \\
\hline 8 & $\begin{array}{l}\text { Horsfeldia } \\
\text { glabra }\end{array}$ & 600 & 0,1 & 0,16 & 3,64 & 3,70 \\
\hline 9 & $\begin{array}{l}\text { Lygodium } \\
\text { circinatum }\end{array}$ & 1.400 & 0,1 & 0,12 & 2,73 & 2,87 \\
\hline 10 & $\begin{array}{l}\text { Borreria } \\
\text { latifolia }\end{array}$ & 1.000 & 0,1 & 0,12 & 2,73 & 2,83 \\
\hline 11 & $\begin{array}{l}\text { Mazuz } \\
\text { japanicus }\end{array}$ & 6.800 & 0,7 & 0,04 & 0,91 & 1,61 \\
\hline 12 & $\begin{array}{l}\text { Microlepia } \\
\text { speluncae }\end{array}$ & 500 & 0,1 & 0,04 & 0,91 & 0,96 \\
\hline 13 & $\begin{array}{l}\text { Borreria } \\
\text { alata }\end{array}$ & 100 & 0,0 & 0,04 & 0,91 & 0,92 \\
\hline & Jumlah & 969.600 & 100,0 & 4,40 & 100,00 & 200,00 \\
\hline
\end{tabular}


Berdasarkan hasil perhitungan, diketahui lima jenis tumbuhan bawah yang memiliki nilai INP tertinggi adalah $P$. conjugatum (103,80), A. gangetica $(32,91)$, C. pubescens (20,58), M. micrantha (14,17), dan I. Cylindrica $(6,75)$. Jenis tumbuhan bawah yang mendominasi di tegakan gaharu adalah $P$. conjugatum, $A$. gangetica dan $C$. pubescens. Kerapatan individu yang tinggi oleh ketiga jenis tumbuhan bawah di atas diduga menyebabkan jenis tumbuhan bawah lainnya tidak memiliki tempat tumbuh. Selain itu, ketiga jenis tumbuhan bawah tersebut dapat memperoleh energi matahari secara optimal yang dapat mendukung proses fotosintesa. Terpenuhinya faktor lingkungan tersebut memacu pertumbuhan tumbuhan bawah yang optimal sehingga mendominasi tempat tumbuh. Dan hal ini sesuai dengan penelitian Yassir dan Sitepu (2014), yang menyatakan bahwa jenis $P$. conjugatum, $M$. micranta dan I. cylindrica adalah spesies yang tumbuh pada lahan terbuka. Intensitas cahaya matahari yang tinggi di tegakan gaharu ini berpengaruh terhadap keragaman jenis tumbuhan bawah. Hasil penelitian Adriadi et al (2012) yang dilakukan di perkebunan kelapa sawit dengan suhu udara dan intensitas cahaya yang tinggi cocok untuk tumbuh dan berkembang secara optimal adalah jenis $P$. conjugatum, $A$. gangetica, M. micrantha dan I. cylindrical. Sehingga hal ini diduga menyebabkan pada tegakan gaharu hanya ditemukan 13 jenis tumbuhan bawah.

Hasil penghitungan nilai indeks keanekaragaman dan kemerataan jenis tumbuhan bawah di tegakan gaharu ditampilkan pada Tabel 10.

Tabel 10. Indeks Keanekaragaman dan Indeks Kemerataan di Tegakan Gaharu

\begin{tabular}{ccc}
\hline No. & Jenis Indeks & Nilai \\
\hline 1 & Indeks Keanekaragaman (H') & 0,72 \\
2 & Indeks Kemerataan (E) & 0,28 \\
\hline
\end{tabular}

Menurut Magurran (1988) dalam Pananjung (2013) jika nilai indeks keanekaragaman $\left(\mathrm{H}^{\prime}\right)<1$ maka tergolong rendah, $\left(\mathrm{H}^{\prime}\right)$ : 1-3 tergolong sedang dan ( $\left.\mathrm{H}^{\prime}\right)$ $>3$ tergolong tinggi. Dengan nilai indeks keanekaragaman (H') sebesar 0,72 seperti tampak pada Tabel 10 menunjukkan bahwa keanekaragaman tumbuhan bawah di tegakan 
gaharu termasuk dalam kategori rendah. Sementara untuk indeks kemerataan (E) menurut Magurran (1988) dalam Destaranti et al. (2017) untuk nilai $\mathrm{E}<0,3$ termasuk dalam kemerataan jenis yang rendah, nilai $\mathrm{E}$ 0,3-0,6 termasuk dalam kemerataan jenis yang sedang dan jika nilai $\mathrm{E}>0,6$ termasuk dalam kemerataan jenis yang tinggi. Dengan nilai indeks kemerataan (E) sebesar 0,28 maka indeks kemerataan tumbuhan bawah di bawah tegakan gaharu termasuk dalam kategori rendah.

\section{d. Tegakan Campuran}

Hasil pengamatan menunjukkan bahwa di bawah tegakan campuran terdapat 11 famili dengan keragaman jenis sebanyak 13, dengan jumlah individu sebanyak 10.328 individu (Tabel 11).

Tabel 11. Jenis, Famili dan Jumlah Individu Tumbuhan Bawah di Tegakan Campuran

\begin{tabular}{|c|c|c|c|c|}
\hline No. & Nama ilmiah & $\begin{array}{l}\text { Nama } \\
\text { daerah }\end{array}$ & Famili & $\begin{array}{l}\text { Jumlah } \\
\text { individu }\end{array}$ \\
\hline 1 & $\begin{array}{l}\text { Asystasia } \\
\text { gangetica }\end{array}$ & $\begin{array}{l}\text { Rumput } \\
\text { israel }\end{array}$ & Acathaceae & 1.645 \\
\hline 2 & $\begin{array}{l}\text { Eupatorium } \\
\text { inulifolium }\end{array}$ & Kirinyu & Asteraceae & 3 \\
\hline 3 & Cyperus & Rumput & Cyperaceae & 14 \\
\hline
\end{tabular}

\begin{tabular}{|c|c|c|c|c|}
\hline & rotundus $L$. & teki & & \\
\hline 4 & $\begin{array}{l}\text { Microlepia } \\
\text { speluncae }\end{array}$ & $\begin{array}{l}\text { Paku- } \\
\text { pakuan }\end{array}$ & Dennstaedtiaeae & 4 \\
\hline 5 & $\begin{array}{l}\text { Centrosema } \\
\text { pubescens }\end{array}$ & $\begin{array}{l}\text { Kacang- } \\
\text { kacangan }\end{array}$ & Fabaceae & 442 \\
\hline 6 & $\begin{array}{l}\text { Melastoma } \\
\text { malabatricum }\end{array}$ & Senduduk & Melastomaceae & 6 \\
\hline 7 & $\begin{array}{l}\text { Horsfeldia } \\
\text { glabra }\end{array}$ & $\begin{array}{l}\text { Akar } \\
\text { amplas }\end{array}$ & Myristicaceae & 6 \\
\hline 8 & $\begin{array}{l}\text { Imperata } \\
\text { cylindrica } L .\end{array}$ & $\begin{array}{l}\text { Alang- } \\
\text { alang }\end{array}$ & Poaceae & 2 \\
\hline 9 & $\begin{array}{l}\text { Paspalum } \\
\text { canjugatum }\end{array}$ & Paitan & Poaceae & 8.065 \\
\hline 10 & $\begin{array}{l}\text { Axonopus } \\
\text { compress }\end{array}$ & $\begin{array}{l}\text { Rumput } \\
\text { karpet }\end{array}$ & Poaceae & 78 \\
\hline 11 & $\begin{array}{l}\text { Borreria } \\
\text { alata }\end{array}$ & $\begin{array}{l}\text { Kentang- } \\
\text { kentangan }\end{array}$ & Rubiaceae & 48 \\
\hline 12 & $\begin{array}{l}\text { Lygodium } \\
\text { circinatum }\end{array}$ & Paku hata & Schizaeaceae & 14 \\
\hline 13 & $\begin{array}{l}\text { Smilax } \\
\text { modesta }\end{array}$ & $\begin{array}{l}\text { Gadung } \\
\text { duri }\end{array}$ & Smilacaceae & 1 \\
\hline & Jumlah & & & 10.328 \\
\hline
\end{tabular}

Pada Tabel 11 terlihat bahwa jenis tumbuhan bawah dengan jumlah individu terbanyak adalah $P$. conjugatum yang termasuk dalam famili Poaceae dengan jumlah individu sebanyak 8.065. Jenis tumbuhan bawah dengan jumlah individu paling sedikit adalah Smilax modesta yang termasuk dalam famili Smilacaceae dengan jumlah individu sebanyak satu. Pada tingkat famili, keragaman jenis tumbuhan bawah yang mendominasi adalah Poaceae yang 
terdiri dari $I$. cylindrica, $P$. conjugatum dan

A. compress.

\section{Tabel 12. Indeks Nilai Penting (INP)}

Tumbuhan Bawah di Tegakan Campuran

\begin{tabular}{|c|c|c|c|c|c|c|}
\hline No. & Nama ilmiah & K & $\begin{array}{l}\mathrm{KR} \\
(\%)\end{array}$ & $\mathrm{F}$ & $\begin{array}{l}\text { FR } \\
(\%)\end{array}$ & INP \\
\hline 1 & $\begin{array}{l}\text { Paspalum } \\
\text { canjugatum }\end{array}$ & 806.500 & 78,1 & 1,00 & 26,60 & 104,68 \\
\hline 2 & $\begin{array}{l}\text { Asystasia } \\
\text { gangetica }\end{array}$ & 164.500 & 15,9 & 1,00 & 26,60 & 42,52 \\
\hline 3 & $\begin{array}{l}\text { Centrosema } \\
\text { pubescens }\end{array}$ & 44.200 & 4,3 & 0,68 & 18,09 & 22,36 \\
\hline 4 & $\begin{array}{l}\text { Axonopus } \\
\text { compress }\end{array}$ & 7.800 & 0,8 & 0,24 & 6,38 & 7,14 \\
\hline 5 & $\begin{array}{l}\text { Horsfeldia } \\
\text { glabra }\end{array}$ & 600 & 0,1 & 0,24 & 6,38 & 6,44 \\
\hline 6 & $\begin{array}{l}\text { Lygodium } \\
\text { circinatum }\end{array}$ & 1.400 & 0,1 & 0,16 & 4,26 & 4,39 \\
\hline 7 & $\begin{array}{l}\text { Borreria } \\
\text { alata }\end{array}$ & 4.800 & 0,5 & 0,12 & 3,19 & 3,66 \\
\hline 8 & $\begin{array}{l}\text { Cyperus } \\
\text { rotundus L. }\end{array}$ & 1.400 & 0,1 & 0,12 & 3,19 & 3,33 \\
\hline 9 & $\begin{array}{l}\text { Melastoma } \\
\text { malabatricum }\end{array}$ & 600 & 0,1 & 0,04 & 1,06 & 1,12 \\
\hline 10 & $\begin{array}{l}\text { Microlepia } \\
\text { speluncae }\end{array}$ & 400 & 0,0 & 0,04 & 1,06 & 1,10 \\
\hline 11 & $\begin{array}{l}\text { Eupatorium } \\
\text { inulifolium }\end{array}$ & 300 & 0,0 & 0,04 & 1,06 & 1,09 \\
\hline 12 & $\begin{array}{l}\text { Imperata } \\
\text { cylindrica } L .\end{array}$ & 200 & 0,0 & 0,04 & 1,06 & 1,08 \\
\hline 13 & $\begin{array}{l}\text { Smilax } \\
\text { modesta }\end{array}$ & 100 & 0,0 & 0,04 & 1,06 & 1,07 \\
\hline & Jumlah & $1,032,800$ & 100,00 & 3,76 & 100,00 & 200,00 \\
\hline
\end{tabular}

Lima jenis tumbuhan bawah dengan INP tertinggi di tegakan campuran adalah $P$. conjugatum (104,68), A gangetica (42,52), C. pubescens $(22,36), A$. compress $(7,14)$ dan $H$. glabra (6,44. Di tegakan campuran P.conjugatum menjadi individu dengan kerapatan tertinggi. Salah satu dugaan yang yang mempengaruhi dominasi $P$. conjugatum adalah tingginya intensitas cahaya matahari di tegakan campuran pada siang hari, yaitu 21.135 (lux). Berdasarkan pengamatan tingginya intensitas matahari tersebut disebabkan oleh variasi tajuk di tegakan campuran. Hal ini dikarenakan jenis pohon dengan tajuk terluas di tegakan campuran adalah sengon yang memiliki ukuran daun kecil. Ukuran daun sengon yang kecil tersebut menyebabkan sinar matahari dapat menembus ke lantai hutan tegakan campuran. Oleh karena itu, tumbuhan bawah dengan kebutuhan cahaya matahari tinggi seperti $P$. conjugatum, A. gangetica dan C. pubescens bisa tumbuh optimal dan menjadi dominan di bawah tegakan campuran. Dominasi ketiga jenis tumbuhan bawah tersebut menekan pertumbuhan jenis tumbuhan bawah lainnya sehingga jenis-jenis tumbuhan bawah yang ditemukan pada tegakan campuran lebih sedikit dibandingkan di bawah tegakan 
meranti. Pada komunitas tumbuhan persaingan antar tumbuhan hidup antar tumbuhan akan mempengaruhi tekanan hidup bagi jenis lain, bahkan jenis tumbuhan yang lain tersebut akan tergantikan dengan jenis tumbuhan lain yang lebih mendominasi. Beberapa faktor yang mempengaruhi persaingan antar komunitas tumbuhan antara lain adalah tempat, cahaya, air dan unsur hara (Indiyanto, 2006).

Hasil penghitungan nilai indeks keanekaragaman dan kemerataan jenis tumbuhan bawah di tegakan campuran ditampilkan pada Tabel 13.

Tabel 13. Indeks Keanekaragaman dan Indeks Kemerataan di Tegakan Campuran

\begin{tabular}{ccc}
\hline No. & Jenis indeks & Nilai \\
\hline 1 & Indeks Keanekaragaman & 0,72 \\
2 & Indeks Kemerataan & 0,28 \\
\hline
\end{tabular}

Hasil perhitungan menunjukkan bahwa nilai indeks keanekaragaman ( $\left.\mathrm{H}^{\prime}\right)$ sebesar 0,72 termasuk dalam kategori rendah, sedangkan nilai indeks kemerataan (E) sebesar 0,28 menunjukkan bahwa indeks kemerataan tumbuhan bawah dibawah tegakan campuran termasuk dalam kategori rendah.

\section{e. Keanekaragaman Tumbuhan Bawah di Tiga Tegakan}

Tabel 14. Indeks Nilai Penting (INP) Tertinggi untuk Tiga Jenis Tumbuhan Bawah di Masing-masing Tegakan Meranti, Gaharu dan Campuran

\begin{tabular}{|c|c|c|c|c|c|c|}
\hline \multicolumn{7}{|c|}{ I. Tegakan Meranti } \\
\hline No. & $\begin{array}{l}\text { Nama } \\
\text { ilmiah }\end{array}$ & $\mathrm{K}$ & $\begin{array}{l}\mathrm{KR} \\
(\%)\end{array}$ & $\mathrm{F}$ & $\begin{array}{l}\mathrm{FR} \\
(\%)\end{array}$ & INP \\
\hline 1 & $\begin{array}{l}\text { Paspalum } \\
\text { conjugatum }\end{array}$ & 354.900 & 69,9 & 0,96 & 16,61 & 86,51 \\
\hline 2 & $\begin{array}{l}\text { Asystasia } \\
\text { gangetica }\end{array}$ & 42.100 & 8,3 & 0,76 & 13,15 & 21,44 \\
\hline 3 & $\begin{array}{l}\text { Centrosema } \\
\text { pubescens }\end{array}$ & 29.700 & 5,8 & 0,84 & 14,53 & 20,38 \\
\hline \multicolumn{7}{|c|}{ II. Tegakan Gaharu } \\
\hline No. & $\begin{array}{l}\text { Nama } \\
\text { ilmiah }\end{array}$ & K & $\begin{array}{l}\mathrm{KR} \\
(\%)\end{array}$ & $\mathrm{F}$ & $\begin{array}{l}\mathrm{FR} \\
(\%)\end{array}$ & INP \\
\hline 1 & $\begin{array}{l}\text { Paspalum } \\
\text { canjugatum }\end{array}$ & 786.100 & 81,1 & 1,00 & 22,73 & 103,80 \\
\hline 2 & $\begin{array}{l}\text { Asystasia } \\
\text { gangetica }\end{array}$ & 116.400 & 12,0 & 0,92 & 20,91 & 32,91 \\
\hline 3 & $\begin{array}{l}\text { Centrosema } \\
\text { pubescens }\end{array}$ & 23.300 & 2,4 & 0,80 & 18,18 & 20,58 \\
\hline \multicolumn{7}{|c|}{ III. Tegakan Campuran } \\
\hline No. & $\begin{array}{l}\text { Nama } \\
\text { ilmiah }\end{array}$ & $\mathrm{K}$ & $\begin{array}{l}\mathrm{KR} \\
(\%)\end{array}$ & $\mathrm{F}$ & $\begin{array}{l}\mathrm{FR} \\
(\%)\end{array}$ & INP \\
\hline 1 & $\begin{array}{l}\text { Paspalum } \\
\text { canjugatum }\end{array}$ & 806.500 & 78,1 & 1,00 & 26,60 & 104,68 \\
\hline 2 & $\begin{array}{l}\text { Asystasia } \\
\text { gangetica }\end{array}$ & 164.500 & 15,9 & 1,00 & 26,60 & 42,52 \\
\hline
\end{tabular}




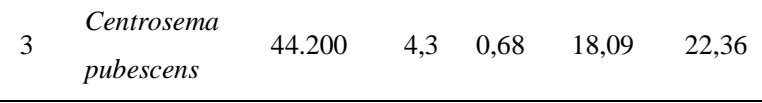

Berdasarkan Tabel 14 terlihat bahwa terdapat tiga jenis jenis tumbuhan bawah yang memiliki nilai INP tertinggi pada 3 tegakan adalah $P$. conjugatum, A. gangetica dan $C$. pubescens. Hasil ini menunjukkan bahwa tiga jenis tersebut memilliki tingkat penyesuaian atau adaptasi yang tinggi terhadap kondisi lingkungan sehingga bisa memanfaatkan sumber daya yang ada berupa unsur hara, air, cahaya, dan ruang yang optimal untuk memacu pertumbuhannya sehingga bisa tumbuh cepat dan akhirnya dominan di ketiga tegakan tersebut. Menurut Indriyanto (2006), faktor yang berpengaruh dalam persaingan kebutuhan yang sama untuk pertumbuhan tanaman dalam suatu komunitas adalah hara, mineral, air, cahaya dan ruang.

Lebih lanjut, berdasarkan hasil pengamatan yang dilakukan terlihat bahwa jenis $P$. conjugatum memiliki nilai INP yang tertinggi. Hal ini menunjukkan bahwa $P$. conjugatum merupakan jenis yang dominan, karena memiliki INP lebih dari $50 \%$, sehingga hal ini menggambarkan bahwa $P$. conjugatum memegang peranan yang sangat penting dalam eksositem di tiga tegakan. Seperti diungkapkan Fachrul (2012) bahwa INP memberikan gambaran pentingnya peran suatu jenis dalam ekosistemnya, semakin tinggi nilai INP berarti semakin penting peran jenis tersebut mempengaruhi kestabilan ekosistem. Hasil yang sama juga ditunjukkan pada penelitian Pananjung (2013), di lahan pasca tambang batubara PT. Kitadin, Kalimantan Timur, bahwa $P$. conjugatum merupakan tumbuhan bawah yang dominan di tegakan sengon buto (Enterolobium cyclocarpum) dengan INP 90,51\%, dan di tegakan trembesi (Samanea saman) dengan INP 82,71\%. Hasil yang hampir sama juga ditunjukkan oleh penelitian Nahdi dan Darsikin (2014), bahwa P. conjugatum dibawah tegakan Acacia auriculiformis di hutan Gama Giri Mandiri Yogyakarta memiliki nilai INP tertinggi kedua dengan nilai 71,05\% di bawah Oplimenus burmanni yang memiliki INP 140,38 \%.

Meskipun demikian, terdapat perbedaan dari nilai INP jenis $P$. conjugatum pada tiga tegakan. Pada tegakan meranti besaran INP-nya $86,51 \%$, sementara di 
tegakan gaharu dan campuran INP-nya di atas angka $100 \%$. Hal ini terjadi karena kerapatan individu $P$. conjugatum di tegakan meranti lebih rendah daripada di tegakan gaharu atau campuran. $P$. conjugatum tumbuh lebih rapat di tegakan gaharu dan campuran sedangkan di tegakan meranti pertumbuhannya kurang begitu rapat (gambar 2, 3 dan 4). Ketika jumlah individu tumbuhan bawah semakin banyak maka nilai kerapatan (K) semakin tinggi dan dan akan meningkatkan nilai INP-nya. Salah satu faktor yang diduga menyebabkan hal ini adalah faktor intensitas cahaya matahari. Pada tegakan meranti, intensitas cahaya matahari lebih rendah dibandingkan intensitas cahaya di tegakan gaharu dan tegakan campuran. Diameter tajuk yang lebih lebar di tegakan meranti mengakibatkan cahaya matahari yang bisa menembus lantai hutan menjadi berkurang, sementara diameter tajuk di tegakan gaharu dan campuran lebih kecil, sehinggga intensitas cahaya mataharinya lebih tinggi. Intensitas cahaya matahari merupakan elemen penting dalam proses fotosintesis untuk menghasilkan karbohidrat. Dengan intensitas cahaya matahari yang rendah akan mempengaruhi proses fotosintesis dan hal ini secara langsung akan mempengaruhi proses pertumbuhan $P$. conjugatum di tegakan meranti. Pada intensitas cahaya matahari rendah, kemungkinan pertumbuhan $P$. conjugatum tidak optimal dibanding plot yang mendapat intensitas cahaya matahari penuh. Dahlan (2011) menyatakan selain cahaya matahari, faktor lain yang berpengaruh besar dalam pertumbuhan tumbuhan di bawah tegakan adalah naungan.

\section{f. Kegunaan Tumbuhan Bawah}

Berdasarkan hasil wawancaradiperoleh informasi bahwa dari 26 jenis tumbuhan bawah yang berada pada tiga lokasi tegakan (meranti, gaharu dan campuran) terdapat 14 jenis tumbuhan bawah yang sering dimanfaatkan sebagai sumber pakan bagi ternak kambing (Tabel 15). 
Tabel 15. Daftar Jenis Tumbuhan Bawah yang Dijadikan Pakan dan Tingkat Kesukaan Kambing terhadap Jenis Tumbuhan Bawah

\begin{tabular}{|c|c|c|c|c|c|c|c|}
\hline \multirow[t]{2}{*}{ No. } & \multirow{2}{*}{$\begin{array}{l}\text { Nama } \\
\text { Ilmiah }\end{array}$} & \multirow{2}{*}{$\begin{array}{l}\text { Nama } \\
\text { daerah }\end{array}$} & \multicolumn{3}{|c|}{$\begin{array}{c}\text { Tingkat } \\
\text { kesukaan }\end{array}$} & \multicolumn{2}{|c|}{$\begin{array}{c}\text { Bagian yang } \\
\text { dimakan }\end{array}$} \\
\hline & & & 1 & 2 & 3 & daun & batang \\
\hline 1 & $\begin{array}{l}\text { Asystasia } \\
\text { gangetica }\end{array}$ & $\begin{array}{l}\text { Rumput } \\
\text { israel }\end{array}$ & $\mathrm{x}$ & & & $\mathrm{x}$ & $\mathrm{x}$ \\
\hline 2 & $\begin{array}{l}\text { Centrosema } \\
\text { pubescens }\end{array}$ & $\begin{array}{l}\text { Kacang- } \\
\text { kacangan }\end{array}$ & $\mathrm{x}$ & & & $\mathrm{x}$ & $\mathrm{x}$ \\
\hline 3 & $\begin{array}{l}\text { Melastoma } \\
\text { malabatric } \\
\text { um }\end{array}$ & Senduduk & & $\mathrm{x}$ & & $\mathrm{x}$ & \\
\hline 4 & $\begin{array}{l}\text { Horsfeldia } \\
\text { glabra }\end{array}$ & $\begin{array}{l}\text { Akar } \\
\text { amplas }\end{array}$ & & & $\mathrm{x}$ & & \\
\hline 5 & $\begin{array}{l}\text { Imperata } \\
\text { cylindrica } \\
L .\end{array}$ & $\begin{array}{l}\text { Alang- } \\
\text { alang }\end{array}$ & & & $\mathrm{x}$ & & \\
\hline 6 & $\begin{array}{l}\text { Paspalum } \\
\text { canjugatum }\end{array}$ & Paitan & $\mathrm{x}$ & & & & \\
\hline 7 & $\begin{array}{l}\text { Axonopus } \\
\text { compress }\end{array}$ & $\begin{array}{l}\text { Rumput } \\
\text { karpet }\end{array}$ & $\mathrm{x}$ & & & & \\
\hline 8 & $\begin{array}{l}\text { Lygodium } \\
\text { circinatum }\end{array}$ & Paku hata & & & $\mathrm{x}$ & & \\
\hline 9 & $\begin{array}{l}\text { Borreria } \\
\text { alata }\end{array}$ & $\begin{array}{l}\text { Kentang- } \\
\text { kentanga } \\
\mathrm{n}\end{array}$ & $\mathrm{x}$ & & & $\mathrm{x}$ & $\mathrm{x}$ \\
\hline 10 & $\begin{array}{l}\text { Smilax } \\
\text { modesta }\end{array}$ & $\begin{array}{l}\text { Gadung } \\
\text { duri }\end{array}$ & & & $\mathrm{x}$ & & \\
\hline 11 & $\begin{array}{l}\text { Mazuz } \\
\text { japanicus }\end{array}$ & $\begin{array}{l}\text { Jukut } \\
\text { mata }\end{array}$ & & & $\mathrm{x}$ & & \\
\hline 12 & $\begin{array}{l}\text { Cyperus } \\
\text { rotundus } L .\end{array}$ & $\begin{array}{l}\text { Rumput } \\
\text { teki }\end{array}$ & & $\mathrm{x}$ & & $\mathrm{x}$ & \\
\hline 13 & $\begin{array}{l}\text { Microlepia } \\
\text { speluncae }\end{array}$ & $\begin{array}{l}\text { Paku- } \\
\text { pakuan }\end{array}$ & & & $\mathrm{x}$ & & \\
\hline 14 & $\begin{array}{l}\text { Gleichenia } \\
\text { linearis }\end{array}$ & Resam & & & $\mathrm{x}$ & & \\
\hline 15 & $\begin{array}{l}\text { Toxocarpus } \\
\text { longipetalu }\end{array}$ & $\begin{array}{l}\text { Toxocarp } \\
\text { us }\end{array}$ & & & $\mathrm{x}$ & & \\
\hline
\end{tabular}

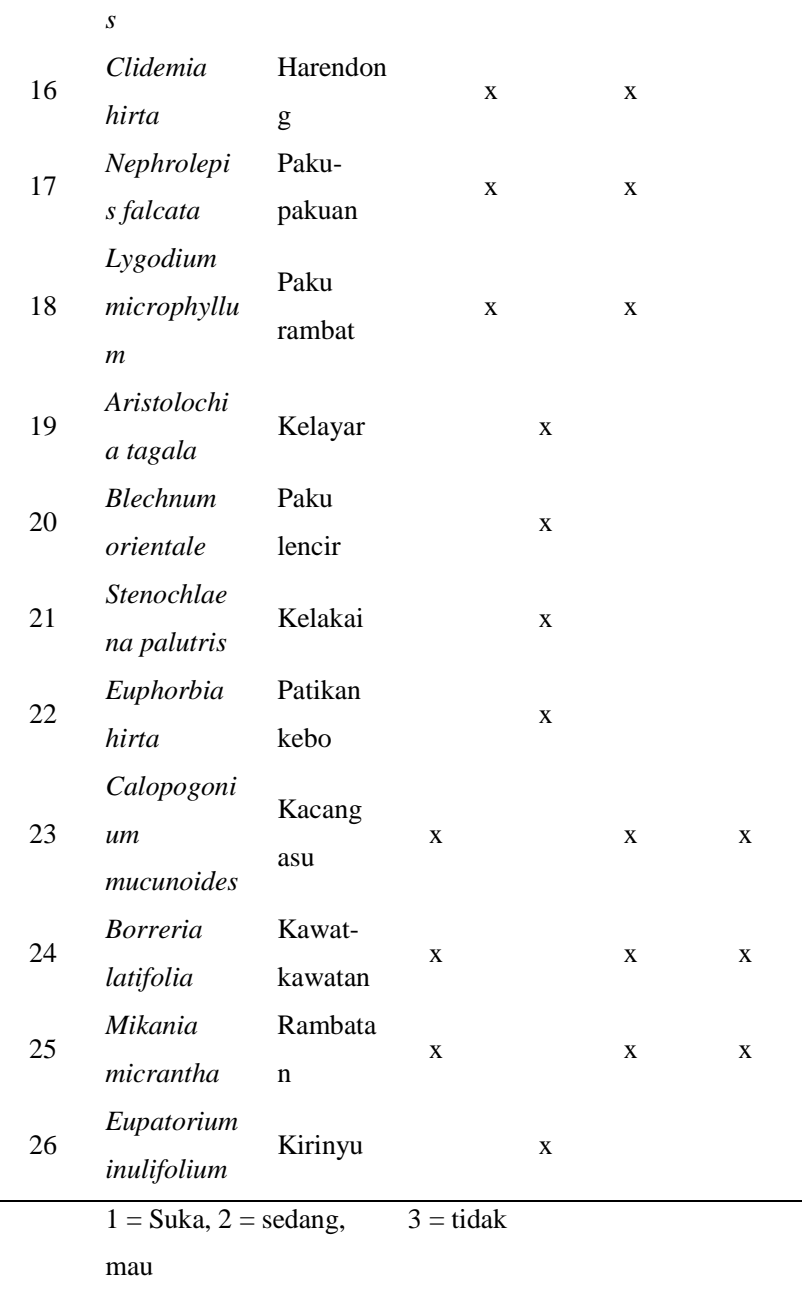

Berdasarkan Tabel 15 diperoleh informasi terdapat 8 jenis $(31 \%)$ tumbuhan bawah yang disukai oleh kambing, 5 jenis (19\%) yang agak disukai dan 13 jenis (50\%) yang tidak disukai. Hal ini memperlihatkan bahwa jenis tumbuhan bawah yang dapat dimanfaatkan sebagai pakan ternak kambing sebesar 50 \%. Hal ini menunjukkan bahwa 
tumbuhan bawah yang dapat dimanfaatkan untuk bahan pakan ternak kambing tidak sedikit., dan tidak juga banyak. Selanjutnya, dari 8 jenis tumbuhan bawah yang disukai oleh kambing, dua jenis diantaranya adalah termasuk dalam famili Poaceae $(P$. conjugatum dan A. compress). Famili Poaceae atau padi-padian adalah jenis tumbuh-tumbuhan berumput yang banyak dipergunakan sebagai pakai ternak, seperti rumput gajah, jagung, padi.

Dalam kegiatan peternakan, dari sebanyak 26 jenis tumbuhan bawah yang ditemukan di tiga lokasi tegakan (meranti, gaharu dan campuran), terdapat 18 jenis yang sering dimanfaatkan sebagai sumber pakan bagi ternak sapi (Tabel 16).

Tabel 16. Daftar Jenis Tumbuhan Bawah yang Dijadikan Pakan dan Tingkat Kesukaan Sapi Terhadap Jenis Tumbuhan Bawah

\begin{tabular}{|c|c|c|c|c|c|c|}
\hline \multirow[t]{2}{*}{ No. } & \multirow[t]{2}{*}{ Nama Ilmiah } & \multirow{2}{*}{$\begin{array}{l}\text { Nama } \\
\text { daerah }\end{array}$} & \multicolumn{2}{|c|}{$\begin{array}{l}\text { Tingkat } \\
\text { kesukaan }\end{array}$} & \multicolumn{2}{|c|}{$\begin{array}{c}\text { Bagian yang } \\
\text { dimakan }\end{array}$} \\
\hline & & & 1 & 2 & daun & batang \\
\hline 1 & $\begin{array}{l}\text { Asystasia } \\
\text { gangetica }\end{array}$ & $\begin{array}{l}\text { Rumput } \\
\text { israel }\end{array}$ & $\mathrm{x}$ & & $\mathrm{x}$ & $\mathrm{x}$ \\
\hline 2 & $\begin{array}{l}\text { Centrosema } \\
\text { pubescens }\end{array}$ & $\begin{array}{l}\text { Kacang- } \\
\text { kacangan }\end{array}$ & $\mathrm{X}$ & & $\mathrm{x}$ & $\mathrm{X}$ \\
\hline 3 & $\begin{array}{l}\text { Melastoma } \\
\text { malabatricum }\end{array}$ & Senduduk & & $\mathrm{x}$ & $\mathrm{X}$ & \\
\hline
\end{tabular}

4

glabra

6

7

8

9

10

11

11

12

13

13

14

15

15

16

17

8

18

19

20

20

21

21

22

23

23
Imperata

cylindrica $L$.

Paspalum

canjugatum

Axonopus

compress

Lygodium

circinatum

Borreria alata

Smilax

modesta

Mazuz

japanicus

Cyperus

rotundus $L$.

Microlepia

speluncae

Gleichenia

linearis

Toxocarpus

longipetalus

Clidemia

hirta

Nephrolepis

falcata

Lygodium

microphyllum

Aristolochia

tagala

Blechnum

orientale

Stenochlaena

palutris

Euphorbia

hirta

Calopogonium

mucunoides
Akar

amplas

Alang-

alang

Paitan $\quad \mathrm{x}$

Rumput

karpet

Paku hata $\quad \mathrm{x}$

Kentang-

kentangan

Gadung

duri

Jukut mata

Rumput

teki

Paku-

pakuan

Resam

Toxocarpus

Harendong

Paku-

pakuan

Paku

rambat

Kelayar

Paku lencir

Kelakai

Patikan

kebo

Kacang asu $\quad \mathrm{x}$ $\mathrm{x}$

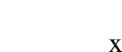

$\mathrm{x}$

X
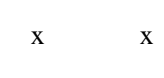

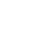




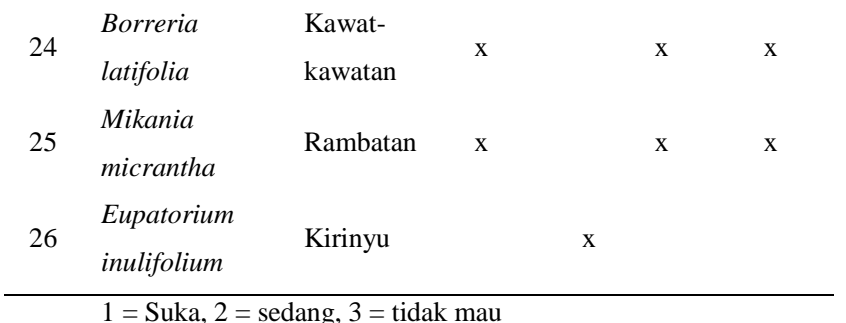

Berdasarkan tabel 16 terlihat ada 8 jenis (31\%) tumbuhan bawah yang disukai oleh sapi, 10 jenis (38\%) yang agak disukai dan 8 jenis $(31 \%)$ yang tidak disukai. Tumbuhan bawah yang ditemukan di lokasi tegakan meranti, gaharu dan campuran yang bisa dipergunakan untuk ternak sapi sebesar $69 \%$. Nilai ini lebih besar dibandingkan dengan tumbuhan bawah yang bisa dipergunakan untuk pakan ternak kambing. Selain itu secara umum sapi memakan lebih banyak tumbuhan bawah dibanding kambing. Hal ini menunjukkan bahwa tumbuhan bawah yang bisa dimanfaatkan untuk bahan pakan ternak sapi lebih bervariasi dibandingkan kambing. Utami (2009) menyebutkan bahwa kandungan protein yang dimiliki rumput jenis P. conjugatum antara 6-8 \%. Yassir dan Sitepu (2015) menyatakan bahwa rumput jenis $P$. conjugatum sejak lama dipergunakan oleh masyarakat untuk pakan ternak. Famili
Leguminosae (polong-polongan) biasanya dipergunakan untuk pakan ternak (Hanafiah, 2005). Jenis tumbuhan bawah yang termasuk dalam famili Leguminosae dalam penelitian ini diantaranya adalah Calopogonium mucunoides, Centrosema pubescens. Hal yang sama juga diungkapkan oleh Karyati dan Adhi (2018) bahwa Calopogonium mucunoides dipergunakan untuk pakan hewan ternak. Ernawati menambahkan bahwa $A$. compress juga dimanfaatkan untuk pakan ternak.

Manfaat tumbuhan bawah untuk bidang kesehatan diperoleh dari narasumber Parno, peramu obat herbal di Desa Pandau Jaya, Kecamatan Siak Hulu, Kabupaten Kampar. Selain wawancara dengan narasumber, informasi manfaat tumbuhan bawah dibidang kesehatan juga diperoleh dari referensi berbagai jurnal dan buku (Tabel 17).

Tabel 17. Manfaat Tumbuhan Bawah di Bidang Kesehatan

\begin{tabular}{|c|c|c|}
\hline No. & Nama Ilmiah & Manfaat \\
\hline 1 & $\begin{array}{l}\text { Asystasia } \\
\text { gangetica }\end{array}$ & $\begin{array}{l}\text { Mengobati batuk, luka dan bengkak, } \\
\text { kejang otot (Karyati dan Adhi, } \\
\text { 2018). }\end{array}$ \\
\hline 2 & $\begin{array}{l}\text { Centrosema } \\
\text { pubescens }\end{array}$ & $\begin{array}{l}\text { Pendingin suhu badan, penetral } \\
\text { racun, (komunikasi pribadi). }\end{array}$ \\
\hline
\end{tabular}


Horsfeldia glabra
Mengobati epilepsi, penetralisir asam pencernaan (komunikasi pribadi dengan Parno ).

Obat kumur sakit gigi diare dan sakit perut ( Yassir dan Sitepu, 2015).

Mengatasi gangguan pencernaan, disentri basiler, diare, hepatitis, keputihan, sariawan haid berlebihan, wasir pendarahan rahim, keracunan singkong, dinding pembuluh darah dan pembekuan (Hartati, 2011). Mengobati sakit mata, sakit perut (Stevani, 2013).

Belum diketahui.

Mengobati sakit ginjal (komunikasi pribadi dengan Parno ).

Pelembut kulit, peluruh air seni, Pembersih darah, penambah nafsu makan, penghenti perdarahan, penyakit ginjal, luka, demam,

tekanan darah tinggi dan penyakit syaraf (Hartati, 2011).

Bahan obat demam dan meluruhkan kencing (Yassir dan Sitepu, 2015).

Obat sakit pinggang (Stevani, 2019).

Penetralisir racun, penstabil suhu,

(komunikasi pribadi dengan Parno ).

Mengobti luka berdarah (Stevani, 2019).

Penetralisir racun, penstabil suhu, (komunikasi pribadi dengan Parno ).

Mengobati luka, (Ernawati, 2009).

Obat untuk menyembuhkan luka-

luka (Yassir dan Sitepu, 2015).

Borreria alata Belum diketahui.

modesta (sepilis), mengobati gatal exim,

(komunikasi pribadi).
11

Mazuz

japanicus

Cyperus

rotundus $L$.

13

14

16

19

20

21

palutris
Microlepia speluncae

Gleichenia

linearis

Toxocarpus

longipetalus

Clidemia

hirta

Nephrolepis

falcata

Lygodium

microphyllum

Aristolochia

tagala

Blechnum

orientale

Stenochlaena

Euphorbia

hirta
Belum diketahui.

Mengobati disentri,, pereda rasa

nyeri (astrigen), (komunikasi pribadi dengan Parno ).

Penyubur rambut, pengatur siklus haid danpenghilang flek hitam pada wajah (Yassir dan Sitepu, 2015).

Mengatasi gangguan sakit dada, sakit gigi, gangguan fungsi pencernaan, haid tidak teratur, sakit waktu haid, keputihan dan menyuburkan kandungan (Pananjung, 2013).

Mengobati saraf dan tulang, (komunikasi pribadi dengan Parno ). Mengobati saraf dan tulang, (komunikasi pribadi dengan Parno ). Menetralisir/melunturkan sel-sel asing, (komunikasi pribadi dengan Parno ).

Menghentikan pendarahan pada luka lecet atau tersayat dangkal (Yassir dan Sitepu, 2015).

Mengobati saraf dan tulang, (komunikasi pribadi dengan Parno ).

Belum diketahui.

Belum diketahui.

Mengobati saraf dan tulang, (komunikasi pribadi dengan Parno ). Mengobati saraf dan tulang, (komunikasi pribadi dengan Parno ). Mengobati bronkitis/saluran pernafasan, tetes mata, asma, (komunikasi pribadi dengan Parno ). Anti bakteri, anti malaria, anti inflamasi, anti jamur obat anti diare, batuk pilek (Karyati dan Adhi, 
2018).

Obat sakit pinggang (Stevani, 2019).

Obat tetes mata (Hadi et al., 2016).
23

Calopogonium

mucunoides

Borreria

latifolia

5

micrantha
Belum diketahui.

Mengobati diabetes (berpasangan

dengan sambiloto), (komunikasi

pribadi dengan Parno ).

Mengobati pendarahan, diabetes,

perut busung/bengkak, (komunikasi

pribadi).

Penawar bisa gigitan serangga dan

kalajengking (Yassir dan Sitepu,

2015).

26

Eupatorium Mengobati diabetes, kulit gatal,

inulifolium (komunikasi pribadi dengan Parno ).

\section{KESIMPULAN DAN SARAN}

\section{a. Kesimpulan}

Kesimpulan dari penelitian

Keanekaragaman dan Kegunaan Tumbuhan

Bawah pada Beberapa Tegakan di Arboretum

Balai Penelitian dan Pengembangan

Teknologi Serat Tanaman Hutan (BP2TSTH)

Kuok adalah sebagai berikut :

1. Tumbuhan bawah yang ditemukan di bawah tegakan meranti terdiri dari 17 famili berupa 23 jenis tumbuhan bawah, dengan jumlah individu sebanyak 10.338. Jenis dengan nilai INP tertinggi adalah adalah $P$. conjugatum $(86,51)$, Indeks keanekaragaman dan kemerataan masingmasing 1,25 dan 0,40. Tumbuhan bawah yang ditemukan di bawah tegakan gaharu terdiri dari 10 famili berupa 13 jenis tumbuhan bawah, dengan jumlah individu sebanyak 9.696. Jenis dengan nilai INP tertinggi adalah adalah $P$. conjugatum $(103,80)$. Indeks keanekaragaman dan Indeks kemerataan masing-masing adalah 0,72 dan 0,28 . Tumbuhan bawah yang ditemukan di bawah tegakan gaharu terdiri dari 11 famili berupa 13 jenis tumbuhan bawah, dengan jumlah individu sebanyak 10.328. Jenis dengan nilai INP tertinggi adalah adalah $P$. conjugatum $(104,68)$. Indeks keanekaragaman dan Indeks kemerataan masing-masing adalah 0,72 dan 0,28.

2. Beberapa tumbuhan bawah yang ditemukan dalam penelitian ini memiliki kegunaan untuk pakan ternak dan kesehatan. Tumbuhan bawah yang bermanfaat untuk pakan ternak kambing sebanyak 14 jenis, pakan ternak sapi sebanyak 18 jenis, sedangkan untuk kesehatan sebanyak 20 jenis. 


\section{b. Saran}

Mengingat adanya keberadaan tumbuhan bawah yang ada di bawah tiga tegakan, manfaatnya dibidang kesehatan masih terbatas, maka perlu dilakukan kegiatan penelitian lanjut tentang manfaat tumbuhan bawah dibidang kesehatan.

\section{DAFTAR PUSTAKA}

Dahlan,M. 2011. Komposisi Jenios Tumbuhan Bawah pada Tegakan sengon (Paraserianthes falcataria $L$. Nielsen). Skripsi. Bogor. Institut Pertanian Bogor.

Hanafiah.2005. Dasar-Dasar Ilmu Tanah. Jakarta. PT. Raja Grafindo Persada.

Indriyanto.2006. Ekologi Hutan. Jakarta : Bumi Aksara

Karyati dan Adhi,MA. 2018. Jenis-Jenis Tumbuhan Bawah di Hutan Pendidikan Fakultas Kehutanan Universitas Mulawarman. Samarinda : Mulawarman University Press.

KLHK.2018. Status Hutan dan Kehutanan Indonesia Tahun 2018. Kementerian Lingkungan Hidup dan Kehutanan Republik Indonesia.

Kunarso A, Azwar F. 2013. Keragaman Jenis Tumbuhan Bawah Pada Berbagai Tegakan Hutan Tanaman di Benakat,Sumatra Selatan. Jurnal Penelitian Hutan Tanaman Vol. 10 No.2 Juni 2013.ISSN : 1829-6327
Soerianegara, I., dan Indrawan, A., 2008. Ekologi Hutan Indonesia. Institut Pertanian Bogor, Bogor.

Yassir,I dan Sitepu,BS. 2015. Jenis-Jenis Tumbuhan Dari Proses Regenerasi Alami Di Lahan Bekas Tambang Batubara. Balikpapan: Balai Penelitian Teknologi Konservasi Sumber Daya Alam Samboja. 